\title{
Ontologism in Semyon Frank
}

\author{
Teresa Obolevitch ${ }^{1}$ (1)
}

Published online: 24 July 2020

(c) The Author(s) 2020

\begin{abstract}
Semyon Frank (1877-1950) opposed the Neo-Kantian School and admitted the real existence of the objects of cognition. He treated ontologism as essential to the entire movement of Russian religious philosophy. For Frank, one can only know about something thanks to the absolute, which exists prior to the knowing subject. Ontologism, affirming the priority of being over cognition, has a great significance not only for metaphysics and epistemology, but also for the philosophy of religion. In particular, Frank taught that the most privileged mode of cognition of God is intuition, an immediate experience of God or faith (the so-called living knowledge). Intuition is at the heart of the ontological proof, which can be found in St. Anselm, Descartes, and Frank himself. Frank dedicated a number of articles to this topic: "K istorii ontologicheskogo dokazatel'stva" ("On the History of the Ontological Proof," 1915), "Ontologicheskoe dokazatel'stvo bytiya Boga" ("Ontological Proof of the Existence of God," 1930), as well as texts recently discovered at the Bakhmeteff Archive, including "Dokazatel'stvo bytiya Boga" ("Proof of the Existence of God"). In this way, Russian ontologism leads to a new interpretation of the traditional ontological proof, one which acknowledges the existence of God, not on the basis of arguments resting on His definition, but on the basis of the intuitive recognition of His being.
\end{abstract}

Keywords Russian philosophy · Semyon Frank · Ontologism · Russian ontologism · Ontological proof $\cdot$ Neo-Kantianism $\cdot$ Cognition $\cdot$ The absolute

\section{Introduction}

The year 2020 ushers in the seventieth anniversary of the death of Semyon Frank (1877-1950). Frank was one of the most prominent representatives of the Russian ontological tradition of all-unity, which presupposes the existence of the all-embracing structure of the universe. In this connection, Frank defended "the primacy of the

Teresa Obolevitch

tereza.obolevich@upjp2.edu.pl

1 Pontifical University of John Paul II, Kraków, Poland 
concept of Being over that of consciousness or knowledge" (Frank 1927, p. 7) - the position that he described as ontologism. In this article, I consider the presuppositions at the basis of ontologism as well as the consequences of this conception for Frank's philosophy of religion. Taking into account archival materials recently discovered at the Bakhmeteff Archive, I dedicate especial attention to his interpretation of the ontological proof.

\section{Frank's Analysis of Judgments}

Like many thinkers of the Silver Age of Russian culture, Frank underwent a long evolution in terms of his worldview-from an initial fascination with Marxism, through idealism, to a shift towards religious philosophy. Frank's epistemological views also evolved. For some time, he admired the teaching of Kant and Neo-Kantianism (Swoboda 1995). In 1904, in the essay entitled "O kriticheskom idealizme" ("On Critical Idealism"), he wrote: "one of the greatest merits of the Kantian theory of cognition is to explain that objectivity, i.e., substantiality, is only a category of consciousness, i.e., a function of our reason" (Frank 1904, p. 233); "Only consciousness, and not being, is the final, absolutely highest and all-encompassing category" (Frank 1904, p. 242).

But in his magister dissertation, Predmet znania (The Object of Knowledge, 1915), Frank clearly distances himself from the views of Kant and Neo-Kantianism. He describes the Marburg School as "valuable and fruitful in many respects," but, at the same time, there is in this system "some discordance, which, upon closer analysis, turns out to be a contradiction" (Frank 1915, p. 72). Frank does not hide his disillusionment with the philosophy of Kant and Neo-Kantianism, because, as he writes, it focuses exclusively on the analysis of cognition whilst leaving metaphysical problems aside.

Like the thinkers of the Kantian School, Frank reflects in his dissertation upon "the nature and conditions of the possibilities of knowledge" (Frank 1915, p. iii) looking for an answer to the question: how is exploring reality possible? All the more, Frank emphasizes the synthetic character of cognition. The author of The Object of Knowledge considers the fundamental question that intrigued Kant and the Neo-Kantians: what enables the relationship between the subject $S$ and the predicate $P$ (in the notation of Frank, between $A$ and $B$ )? On what basis can it be concluded that " $A$ is $B$ " when each element of the judgment is submitted to the law of identity: $A$ is $A$ and $B$ is $B$ ? Frank writes that, if $A$ had been connected with $B$ from the very beginning (in the form of $A B$ ), it would have to be said that " $A$ is $A B$," i.e., " $A$ is non- $A$," which is patently absurd. In turn, the notation " $A B$ is $B$ " (suggested, in Frank's opinion, by Lotze) expresses an ordinary tautology that does not expand our knowledge. Therefore, $A$, on the one hand, is not connected with $B$, while, on the other, it is not completely isolated, in which case it would be impossible to gain new knowledge. Hence, it can be assumed that $A$ is connected with something else, namely an unknown and undefined $x$. We therefore get the formula (1) $A x$.

Accordingly, the original notation " $A$ is $B$ " should be replaced by (2) " $A x$ is $B$." The symbol $x$ expresses the orientation of our cognition towards something that 
remains unknown and that will be further determined as $B$. In this formula, $x$ is a condition for the possibility of all cognition. In every epistemic act, there is some "surplus" $(x)$, which allows us to state that $A$ is not only $A$, but also $B$, so that our knowledge is broadened. Element $x$ is a primordial, fundamental one in relation to the specific content $A, B, C$, etc. Only on the basis of $x$, which is unknown and undefined, can we state the content of both $A$ and $B$ (and, respectively, $C, D, E$, etc.). Element $A$, which is considered to be the logical subject of the judgment, and element $B$, which is considered to be the predicate, are de facto derivatives of element $x$, which is a potential source of all terms. Therefore, " $A x$ is $B$ " is equivalent to the formula (3) " $x$ is $A$," which means that $x$ "contains" $A$ in itself, although it is not exhaustive in this element. Element $A$ is only the specific content of an unspecified object $x$. This leads to the formula (4) " $x$ is $A B$." Element $x$ represents a "background" for every act of knowledge, for all possible predicates. On the basis of this reasoning, Frank draws two conclusions. First, the pattern " $x$ is $A$ " supposes that "we know what we do not know." Secondly, it means that "what we do not know is for us the basis and the support of that which we know" (Frank 1915, p. 25).

Subject $A$ and predicate $B$ of the initial formula " $A$ is $B$ "- due to their mutual exchangeability — do not express the object, matter, or content of the judgment. However, they are reflected in the obtained formula " $x$ is $A B$." It is $x$ that is the real object of the judgment ("that we are talking about something") and the complex $A B$ is the real content ("what we are talking about"). In other words, the relationship between $A$ and $B$ cannot be explained in the judgment $A$ is $B$ unless we accept the existence of the transcendent object $x$, which is the source of all the concepts: $A, B, C, D$, etc.

Frank's conclusion becomes clearer if we treat the subiectum and praedicatum of synthetic judgments as equivalents to Aristotle's substance and property. The Russian philosopher was convinced that the true "substance" is not a logical subject $(A)$, but a transcendent object $x$. All the individual terms $(B, C, D$, etc.), including the term $A$, are "properties," or rather "determinations" of the object $x$, identified by Frank with the absolute or all-unity.

Frank stressed that the subject and the predicate of the judgment should be considered in their "internal" unity. In support of this argument, the author of The Object of Knowledge referred to Kant, who wrote in his Critique of Pure Reason:

I have never been able to settle for the explication that logicians give of a judgment as such. A judgment, they say, is the presentation of a relation between two concepts. [...] But suppose that I inquire more precisely into the [relation or] reference of given cognitions in every judgment [...]. I then find that a judgment is nothing but a way of bringing given cognitions to the objective unity of apperception. (Kant 1996, pp. 183-184, B 141)

For Frank, as for Kant, the object $x$ plays a synthesizing function, enabling the combination of various representations in the shape of a judgment. However, the author of the Critique of Pure Reason treated this $x$ (which he called a transcendental object) purely subjectively: "combination does not lie in objects, and can 
by no means be borrowed from them by perception and thus be taken up only then into the understanding" (Kant 1996, p. 179, B 135). Frank, on the contrary, considered the object $x$ (the absolute or all-unity) to be objectively existing per ipsum.

Frank wants to overcome Kantian subjectivism and to show that the ultimate condition of cognition is not the activity of the subject, but the absolute, containing all beings, including the subject that knows it. He writes:

Being is a primordial principle, the root of everything else, including all doubt and denial, and, therefore, something utterly and absolutely undeniable. [...] Reality does not merely send a representative to our consciousness; it is, so to speak, a living presence within us. Therefore, we can already say that this reality - as every true reality-is independent of its subject, precisely in the same sense in which it is independent of the opinions and ideas of the subject. (Frank 1928, pp. 329-330)

Kant considered only two conditions under which the subject and the object could meet: "either if the object makes the presentation possible, or if the presentation alone makes the object possible" (Kant 1996, p. 147, B 125). Frank proposes a third solution: this connection is realized by anchoring both the object and the subject in a common sphere of all-unity that is transcendent to individual beings and that, at the same time, is immanent and constitutes their ontological foundation (Frank 1915, p. 204).

The representatives of the Neo-Kantian Marburg School sharpened the criticism of Kant. For Kant, the thing-in-itself was unknowable, but it existed. NeoKantian philosophers treated this as a remnant of the old metaphysics; for them, to suppose the existence of a thing-in-itself is nonsense and objective existence can be determined only in relation to cognition. Referring to the fact of the constant development of scientific knowledge, the Neo-Kantians claimed that the process of learning is always in statu fieri and never ends. This, in turn, means that the total determination of the object is unattainable. We cannot speak of an object as such, because it is constructed only in the process of cognition. Like Kant (and Frank), the philosophers of the Marburg School understood cognition as a synthetic connection of the captured elements. According to Paul Natorp, the process of cognition is a progressive movement, but the object constantly "eludes" us: we are unable to know all its aspects in their mutual relations. On this basis, Hermann Cohen claims that the object, the unknown $x$, is not given (gegeben) to knowledge, but is in fact a task (Aufgabe) (Natorp 1912, p. 200).

In The Object of Knowledge, Frank agrees with the Neo-Kantian thesis that the process of cognition is a task. At the same time, however, he makes an important stipulation that leads him to a radically different conclusion. Frank notes, in particular, that the "task is not itself an object, like $x$, that is to be determined. The 'task' is only its determination, while the $x$ itself is prior to cognition, like the given is prior to its condition" (Frank 1915, p. 73). A little further on, Frank develops his thought in the following way: 
In knowledge (in the broad sense of the word), the object, admittedly, figures as an $x$, as a goal to be realized, i.e., as an unknown, the internal determination of which ought to be discovered. However, this function-as the analysis of the objective idealism of the "Marburg School" has particularly made clear-cannot exhaust all its meaning. On the contrary, it requires that this goal should be thought of as existing before and independently of the activities of its realization. (Frank 1915, p. 101)

In short, unlike the Neo-Kantian philosophers who proclaimed the primacy of cognition over being, Frank was convinced of the primacy of being over cognition. The "logic of pure cognition" of the Marburg School (Logik der reinen Erkenntnis), i.e., the theory of cognition "without object," was replaced by the Russian thinker with the "ontology of cognition." He wrote that cognition is possible "only on the condition that knowledge of the subject and object are rooted not in some consciousness, as it has been assumed, but in the absolute being, as an immediate and undetachable presence with us and in us, the primordial unity which makes possible the dichotomy of the knowing consciousness and the object" (Frank 1915, pp. iii-iv). For this reason, as Frank notes, "there is no 'gnoseology' without 'ontology.' Since the very concept of knowledge means knowledge of an object, it is impossible to examine any knowledge without examining the object of knowledge" (Frank 1915, p. v); "we can cognize and know being because we not only know, but also exist; first we must be, and only then-get to know. Primum esse, deinde cognoscere" (Frank 1915, p. 168). Frank, therefore, stressed the objective existence of the object of knowledge. According to him, the $x$ (the absolute or all-unity) is not a construct of the mind, a result of cognition, but a foundation and condition of any epistemic process which relies on the increasingly precise determination of all contents contained in the $x$. Individual notions do not express the process of cognition, in the sense of a "creation" of reality — as the Neo-Kantians suggested —, but constitute a "detailed moment" in the structure of the all-encompassing, absolute object $x$.

Frank wrote that the "content" of an object of cognition, its specific predicates, are already "contained" in the absolute. Although the notions $A, B, C \ldots$ as such, that is, as specific notions, are not "accessible" to us before we know them, they nevertheless exist objectively, because they are united as potential elements of the original, undifferentiated set (all-unity), which is the substratum of a subsequent differentiation. The cognitive determination of individual terms occurs as a result of distinguishing them from other terms: $A=(x-B C D), B=(x-A C D)$, etc. (Frank 1915, p. 268). Referring to Nicholas of Cusa (whom Frank considered to be his "only teacher of philosophy"), as well as to the German idealists (Fichte, Schelling, and Hegel), the Russian thinker argued that the determination of the particular attributes of the object is a "dissection into a system of notions and their correlation of what should be directly given in the form of unity, which precedes the system of content expressed by notions" (Frank 1915, p. 205). Elsewhere, Frank, referring to Spinoza's famous statement, omnis determinatio est negatio, wrote: "the fundamental condition of all knowledge is differentiation, and the tool or instrument of differentiation is negation" (Frank 1983, p. 77). The 
dissection or "objectification" of specific attributes is thus a result of the differentiation of the absolute object of knowledge, i.e., the all-unity.

\section{Frank's Ontologism}

The question thus arises: does Frank, proclaiming the priority of being over cognition, not return to the position defined by the Neo-Kantians as "dogmatic," which aspires to the uncritical acceptance of the objective existence of reality and of the possibility of its cognition? The answer is not obvious at all. Frank, further developing the thought of Nicholas of Cusa, clearly states that $x$ as an object of knowledge (i.e., the absolute or all-unity) is a condition of every act of cognition. But, at the same time, this $x$ remains uncognizable, incomprehensible. The term $x$, perhaps borrowed from Kant (who used it as a sign of the "transcendental unity of apperception"), takes on a very specific meaning in Frank's later works (especially in his treatise The Unknowable: An Ontological Introduction to the Philosophy of Religion, 1939), namely it reflects the thesis of the unknowable, "metalogical" nature of the absolute as an object of cognition.

In Frank's opinion, the absolute potentially includes all possible terms $(A, B, C$, etc.), but as such is of a "metalogical" nature, thus exceeding our possibilities of a conceptual approach to it. Frank criticizes the position of Neo-Kantian philosophers who maintained that being does not exist independently of cognition. But, at the same time, he agrees with them (although for different reasons) that the ultimate object of knowledge - the absolute- "escapes" any determination or description. In other words, the Russian philosopher is a "dogmatist" in the sense that he recognizes the independent, objective (what is more, absolute!) existence of the object of cognition. Nevertheless, he is far from acknowledging the possibility of a final, total knowledge of it.

Frank conceives his own philosophy as carrying out the task of Russian philosophy, which he sees as moving in the direction of ontological realism, i.e., towards ontologism:

The usual forms of cognition leave us unsatisfied because, as Jacobi showed, they are grounded only on an ideal bond between subject and object and hence the object only ideally, without in fact penetrating to its inner reality. But the main task of Russian philosophy was precisely movement toward real being, real penetration into being itself. Russian philosophy is engaged in a constant struggle with Kantianism and with any form of subjective idealism. (Frank 1992, pp. 41-42)

Hence, as Frank explains, '[t]here is no 'gnoseology' without 'ontology.' Since the very notion of knowledge means knowledge of the object, it is impossible to examine any knowledge without examining the object of knowledge" (Frank 1915, p. v).

While the representatives of the Marburg School (including Hermann Cohen, among others) claims that "to think is to be, to be is to think" (Denken ist Sein, Sein ist Denken), Frank-paraphrasing Descartes-preaches the principle: Cogito, ergo 
est esse absolutum. In accordance with the principle of ontologism, he proposes a metaphysical model of all-unity, which is the condition of all knowledge, and the direct recognition of which (in an act of "faith" or intuition) constitutes the basic form of knowledge. One can observe a mutual relation between the gnoseological and ontological considerations of Frank. On the one hand, his epistemological research assumes a certain metaphysical characteristic of the object of knowledge and, on the other hand, his original conception of being arises in the process of the epistemological analyses. As Frank writes: "the theory of knowledge-znanie, consistently thought through, is transformed into the theory of truth or being; and gnoseology again consciously becomes what every philosophy is unconsciously: general ontology" (Frank 1993, p. 24).

As we have seen, Frank's conviction about the independence of being from the process of cognition was formed under the undeniable influence of Nicholas of Cusa. In The Object of Knowledge, he quotes words from the latter's work Compendium (Chapter I): "Negari nequit, quin prius natura res sit, quam sit cognoscibilis" ("we cannot deny that by nature a thing exists before it is knowable") (Frank 1915, p. v; cf. Nicholas of Cusa 1996, p. 1386). Frank also accuses the Neo-Kantians of failing to draw the proper metaphysical conclusions from Nicholas of Cusa's teachings, despite their fascination for his writings (Elen 2004, p. 194; Elen 2005, p. 334).

In his lecture titled "Die russische Weltanschauung" ("The Russian Worldview") delivered on the $26^{\text {th }}$ of May 1925 in Berlin during a meeting of the Kant Society and subsequently published as a book, Frank stressed that for Russian philosophy

Gnoseology - although in a completely different sense-is no less relevant than for German thought. The idea and style of the theory of knowledge in Germany, in its well-known form, which originates from Kantianism and is internally connected with it, is diametrically different from that which can be called the essence of Russian philosophy. [...] The critique of Kant's philosophy and the fight against Kantianism are among the permanent themes of Russian philosophical thought. [...] For the Russian spirit, the path from cogito to sum has always seemed absolutely artificial; for him, the true path always leads from sum to cogito. [...] There is no need to "know" something first in order to penetrate being; on the contrary, in order to know something, one must first be. (Frank 1926, pp. 9, 11-13)

Approaching epistemological issues from the point of view of the paradigm of "ontologism," Frank wants to restore the rights of citizenship to metaphysics. For this very purpose, he develops the ontological concept of all-unity (the absolute), which, in Frank's opinion, grounds the cognition of all things. It is no coincidence that Frank's work The Object of Knowledge has been labeled the "Russian Critique of Pure Reason" (Evlampiev 2000, p. 359). For it contains both the epistemological and the ontological program of Russian thought during the Silver Age. According to Frank's own confession: "I, emphasizing the thorough-going unity of Being and the consequent systematic unity of concepts, reach a point of view representing a reformulation and revaluation, in the direction of ontologism, of the Hegelian philosophy and of the logical doctrines of the so-called 'Marburg school"' (Frank 1927, p. 9). For him, ontologism "may be considered as a typically national trait of 
Russian philosophical thought," whereby "the division of philosophy into the theory of knowledge and ontology is untenable, because all philosophy, and therefore also the theory of knowledge itself, is already ontology" (Frank 1927, p. 10). In Frank's opinion, as a feature of Russian philosophy, ontologism allows to better understand the classical proofs for God's existence-not in the sense of a syllogistic proof, a result of intellectual investigation, but as an intuitive form of cognition.

\section{The Ontological Proof}

Although ontologism is of a metaphysical and epistemological nature, it also has implications for the philosophy of religion. In particular, Frank teaches that the most privileged way of cognition of God is intuition, an immediate experience of God or faith (so-called living knowledge). In his essay "Wesen und Richtlinien der russischen Philosophie" ("The Essence and Leading Themes of Russian Philosophy," 1925), Frank claims: "The whole of Russian thought is pervaded by the concept of living, intuitive experience" (Frank 1992, p. 41). Frank and Nikolai Lossky (1870-1965) shared a version of intuitivism according to which "the cognized object, even if it forms part of the external world, enters the knowing subject's consciousness directly, so to speak in person, and is therefore apprehended as it exists independently of the act of knowing" (Lossky 1951, p. 252). Frank called this sort of intuition "living knowledge." At the same time, Frank was influenced by Bergson's concept of intuition as "integral experience" and tried to unite "pure gnoseology" with "pure ontology" in the form of ontologism. Both Lossky and Frank were "drawn to Bergson's philosophy because they found compelling parallels between Bergsonian intuition and the Orthodox concept of immediate, noncognitive understanding by which man is capable of attaining the absolute" (Fink 1999, p. 28). Cognition of being, especially of God as absolute being, presupposes its real, unquestionable existence, i.e., the world's ontological foundation.

The Russian philosopher wrote that intuition is at the heart of the ontological proof that can be found in many philosophers, such as St. Anselm, Nicholas of Cusa, Bonaventure, Malebranche, Descartes, and Frank himself. Frank dedicated a number of his articles to this topic: "K istorii ontologicheskogo dokazatel'stva" ("On the History of the Ontological Proof," 1915), in which he reconstructed in details the development of this idea starting from Parmenides up to Hegel, as well as "Ontologicheskoe dokazatel'stvo bytiya Boga" ("Ontological Proof of the Existence of God," 1930), and newly discovered drafts of Frank's lectures (written in 1930 and published in 2017), namely, "Dokazatel'stvo bytiya Boga" ("Proof of the Existence of God") and "Ontologicheskoe dokazatel'stvo bytiya Boga" ("Ontological Proof of the Existence of God"), the manuscripts of which are stored at the Bakhmeteff Archive of Russian and East European Culture at Columbia University. In this way, Russian ontologism results in a new interpretation of the traditional ontological proof, which acknowledges that the existence of God is possible, not on the basis of the analysis of His definition, but on the basis of the intuitive recognition of being, which is in tune with Orthodox spirituality. For this reason, Frank avoided the expression "proof of God's existence" in favor of "mystical intuition" (Frank 1972, p. 137). 
Frank distinguishes between two types of proof of God's existence: The first type proceeds "from the structure of the world to God" (i.e., "empirical proof") and "through any reasoning that directly achieves the idea of God" ("rational proof") (Frank 2017a, p. 191). This is the case, for instance, with Aristotle's argument for the existence of the Prime Mover and with Aquinas' Five Modes. Nevertheless, as Frank observes, "[r] eflections on the world rather lead to atheism (or to the teaching of the powerless God-which is very common-like the new Gnosticism). To overcome this, faith is needed" (Frank 2017a, p. 192).

The second type of proof for the existence of God proceeds "from the idea" to which the ontological proof as such relates. Frank claims that this type of ontological proof is valuable because it is "not a 'proof' in the sense of inference, but rather a directing of consciousness at the perception of self-evidence" (Frank 2017b, p. 96). Hence, the truth comprehended in the latter type of ontological proof can be described as being a necessity of another order: "the primary or absolute necessity, combining in itself categoricality with apodicticity" (Frank 1972, p. 122). In other words, ontologism is a necessary condition for the cognition of God by means of the latter type of "ontological proof." For him, it is

necessary to demonstrate that true metaphysical being - and, in the final analysis, the being of God-is open to man, that consciousness not only grasps being but in fact always proceeds from being. [...] "absolute being" [...] lies beyond the opposition between subject and object and is the ground of the two sides of this opposition in that it is itself primary and self-evident being. (Frank 1992, p. 42)

Frank also distinguishes two kinds of faith: faith as confidence (obedience to authority) and faith as certainty (or faith as knowledge), the latter of which relies on the personal, immediate, intuitive perception of God (Frank 1946, pp. 13-29). In his opinion, "[f]aith consists of the awareness that Truth in this sense coincides with that which truly is, the ultimate ground and the universal creative source of all that exists" (Frank 1946, pp. 138-139). Faith is not a result of logical inference, a transition from only a conceivable hypothetical existence of God to the assertion of His real existence, but the "living knowledge," the fruit of the vision of God. In this regard, the ontological proof is not a proof in the strict sense of the word; it is a testimony, a description of the personal experience of meeting God.

According to Frank, "the ontological proof can be applied just to the whole allembracing unity" (Frank 1928, p. 349). God is not outside of man, because in Him we "live, and move, and have our being" (cf. Acts 17:28), despite the fact that God is infinitely greater than the whole of creation. Frank regards Christianity through the prism of panentheism. If God is immanently present in the world (and, at the same time, transcends it), then the cognition of God is not an act of rational reflection aimed at an external abstract object, but a living mystical connection with Him. As Frank explains,

The meaning of the ontological proof does not consist in the fact that through the analysis of an abstract idea, which has no necessary connection with reality, we, with the help of some magical inferences, some logi- 
cal "trick," arrive at the affirmation of reality, but simply that here we from the very beginning have not an abstract idea, but rather the very fullness of reality, and peering into it, we see that otherwise we could not have such an object at all, i.e., that the usual logical distinction between an "idea" and "reality" is here unfeasible. (Frank 1972, p. 115)

The ontological proof has universal scope in terms of application. It expresses "the presence of such content of knowledge [i.e., the content of knowledge of the being of God-T. O.], in relation to which being and thought, or 'existence' and 'essence' are so inseparably connected with each other that it is impossible to recognize the second without recognizing the first" (Frank 1915, p. 439).

For Frank, the classical model of the ontological proof can be found in The Enneads of Plotinus (IV, 7, 9), in which the ancient thinker developed the Platonic idea of the immortality of the soul. Plotinus claimed that the soul in its essence is immortal, while at the foundation of this immortality lies a being that exists with absolute necessity, that is, the essence of which is existence. Therefore,

The very word ["Being"-T. O.], strictly used, means that the thing is perdurable. Similarly white, the colour, cannot be now white and now not white: if this "white" were a real being it would be eternal as well as being white: the colour is merely white but whatsoever possesses being, indwelling by nature and primal, will possess also eternal duration. In such an entity this primal and eternal Being cannot be dead like stone or plank: it must be alive, and that with a life unalloyed as long as it remains self-gathered. (Plotinus 1956, p. 353; Frank 1915, p. 452)

In other words, the assumption of the absolute being, the essence of which coincides with its existence, is the justification for a being with a lower degree of excellence.

Frank emphasizes that the "ontological proof expresses the mystery of Godthe impregnable light in which He lives" (Frank $c$. 1936). If Frank's interpretation of the ontological proof is correct, then the Kantian critique of the ontological proof misses the target because it is based on completely different assumptions. As Vyacheslav Kotsyuba says, "what in Frank appears under the sign of identity (being and necessary thought), differs clearly in Kant and even, in a certain sense, appears opposite" (Kotsyuba 2001, p. 401).

It is noteworthy that Frank, analyzing the traditional formulation of the ratio Anselmi, shares the Kantian criticism that the move from the mental word to the real order is unjustified, artificial, and even "magical." At the same time, he was perhaps the first philosopher of the twentieth century to draw attention to the difference between the versions from the second and third chapters of St. Anselm's Proslogion. Frank believed that Anselm avoids the false supposition in the second version of the proof, according to which God is immediately stated as a real being. Both in Predmet znania (1915, pp. 450-465) and in "Ontologicheskoe dokazatel'stvo bytiya Boga" (1972, p. 125), Frank finds support in the following passage from the Proslogion: 
Assuredly, this [being] exists so truly [i.e., really] that it cannot even be thought not to exist. For there can be thought to exist something which cannot be thought not to exist; and this thing is greater than that which can be thought not to exist. Therefore, if that than which a greater cannot be thought could be thought not to exist, then that than which a greater cannot be thought would not be that than which a greater cannot be thought-[a consequence] which is contradictory. Hence, something than which a greater cannot be thought exists so truly that it cannot even be thought not to exist. And You are this [being], o Lord our God. Therefore, o Lord my God, You exist so truly that You cannot even be thought not to exist. (Anselm of Canterbury 2000, p. 94)

It is believed that the idea of a new understanding of the ontological proof belongs to Karl Barth, who published in 1931 the work entitled Fides quaerens intellectum. Anselms Beweis der Existenz Gottes, which contains the results of his seminars on the theological treatise of Anselm Cur Deus homo delivered at the University of Bonn in 1930 (Dushin 2014, pp. 51-53). However, it should be remembered that Barth also referred to the work of a philosopher from Russia, Alexandre Koyré (1892-1964) (Koyré 1923). In turn, Frank himself wrote: "Afterwards, when, in my book The Object of Knowledge, I had tried to find out the true meaning of the ontological proof of Anselm [...], my interpretation was confirmed by the excellent analysis of this theme presented in a purely historical work of A. Koyré, L'idée de Dieu chez Anselm" (Frank 1972, p. 126). ${ }^{1}$ This implies that it was Frank who was truly at the beginning of the new reading of the ontological proof, although his writings were undeservedly underestimated by the international philosophical community. Nowadays, both versions of the ontological proof as well as the difference between them are also the subject of studies in the field of analytic philosophy (Szatkowski 2012). But it was Frank who initiated the idea of considering the third rather than the second chapter of Proslogion as the most substantial and adequate representation of the Anselmian argument, which had been developed over the centuries by many other thinkers.

In his book The Unknowable, Frank wrote:

All the opponents of the ontological proof start from the same assumption (which seems to be self-evident), namely, that God is a special, existent "object" of thought. But this is precisely what the ontological proof denies. (It is only in its less successful and therefore more popular formulations that the proof is made to start from this assumption, which is to be refuted later). The true meaning of the ontological proof is not that one can "deduce" (by inference) the real being of God from the pure idea of God as a hypothetical content of a concept (which is indeed absolutely impossible, and the triumph of the opponents of the proof consists in a cheap victory over this formulation). On the contrary, its true meaning is that it shows that Divinity is a reality which cannot be given as a pure idea but is always directly revealed to us as a full-fledged, concrete reality. (Frank 1983, pp. 216-217)

\footnotetext{
${ }^{1}$ The title of Koyré's book is actually L'idée de Dieu dans la philosophie de St. Anselme (Koyré 1923).
} 
In Frank's interpretation, the ontological proof is not a particular subject of the philosophy of religion, but an expression of its very essence. Religion, as Vladimir Solovyov taught, is "the connection of humanity and the world with the absolute principle" (Solovyov 1995, p. 1), and this connection presupposes the possibility and even necessity of a direct perception of the existence of God. This is precisely the manner in which Frank interprets the ontological proof. As Jaromír Feber remarks, the "system of Frank shows that the premise of God is no less acceptable than those accepted by modern philosophy" (Feber 2015, p. 214). The philosopher himself, clearly arguing with the Kantian understanding of religion, planned to write a piece entitled Religion Within the Limits of Experience or Religion as Experience; in his working notes, he wrote that "religion is cognized not by means of thought; the reality with which it deals can only be either directly 'perceived,' grasped, felt, or it is absent for us. This means that religion is basically experience" (Frank 2016, p. 518).

According to Frank, the starting point of religion is not the individual things given in empirical experience, the acceptance of the existence of which might require the acceptance of the First cause, but the supposition of the existence of God, the foundation for all beings, of their existence and of our knowledge of them. In this case, we have

the transition from the primacy of consciousness, which he [i.e., Frank-T. O.] called "epistemologism," to the primacy of being, called "ontologism." The transition, however, did not rely on a simple reversal of Descartes' approach, but on its deepening. The proof of the existence of a subject, namely cogito ergo sum, was to be transformed into a proof of the existence of an absolute being, namely cogito ergo est esse absolutum. (Rojek 2019, p. 120)

Indeed, ontologism is key to the theological and philosophical reflections of Frank, for whom being - nay, absolute being - is primary to cognition, as we have seen by means of the example of his interpretation of the ontological proof.

Acknowledgements This publication was generously supported by a Grant from the Foundation of the Copernicus Center for Interdisciplinary Studies "Humanities in Dialogue" financed by the Ministry of Science and Higher Education of Poland in the framework of the programme "Dialogue"; No 0239/ DLG/2018/10.

\section{Compliance with ethical standards}

Conflict of interest The author declares that she has no conflict of interest.

Open Access This article is licensed under a Creative Commons Attribution 4.0 International License, which permits use, sharing, adaptation, distribution and reproduction in any medium or format, as long as you give appropriate credit to the original author(s) and the source, provide a link to the Creative Commons licence, and indicate if changes were made. The images or other third party material in this article are included in the article's Creative Commons licence, unless indicated otherwise in a credit line to the material. If material is not included in the article's Creative Commons licence and your intended use is not permitted by statutory regulation or exceeds the permitted use, you will need to obtain permission directly from the copyright holder. To view a copy of this licence, visit http://creativecommons.org/licen ses/by/4.0/. 


\section{References}

Anselm of Canterbury (2000). Proslogion. In Complete Philosophical and Theological Treatises of Anselm of Canterbury. Trans. J. Hopkins. Minneapolis: The Arthur J. Banning Press, pp. 88-112.

Dushin, O. Ė. (2014). 'Ontologicheskii' argument v interpretatsii S. L. Franka. Mysl', vol. 16, pp. 47-54.

Elen, P. (2004). Vvedenie v spetsifiku filosofskogo myshleniya Franka. Trans. O. Nazarova. Logos, vol. 1, pp. 186-208.

Elen, P. (2005). Nikolay Kuzanskiy i Semen Frank. Trans. O. Nazarova. In N. V. Motroshilova (ed.), Istoriko-filosofskiy ezhegodnik' 2005. Moscow: Nauka, pp. 331-358.

Evlampiev, I. I. (2000). Istoriya russkoy metafiziki v XIX-XX vekakh. Russkaya filosofiya v poiskakh absolyuta. Part I. Sankt-Petersburg: Aletheia.

Feber, J. (2015). S. L. Frank i obosnovanie religioznoy filosofii. In J. Feber, J. Petrucijová (eds.), Ruská filozofie a jeji reflexe v Česku a na Slovensku. Ostrava: Vysoká škola bášká-Technická univerzita Ostrava, pp. 213-223.

Fink, H. L. (1999). Bergson and Russian Modernism, 1900-1930. Evanston: Northwestern University Press.

Frank, S. L. (1904). O kriticheskom idealizme. Mir Bożiy, vol. 12, n. 2, pp. 224-264.

Frank, S. L. (1915). Predmet znaniya. Ob osnovakh i predelakh otvlechennogo znaniya. Petrograd: Tipografiya R. G. Shredera.

Frank, S. L. (1926). Die russische Weltanschauung. Berlin: Pan-Verlag Rolf Heise.

Frank, S. L. (1927). Contemporary Russian Philosophy. Trans. K. Schmidt, E. L Schaub, The Monist, vol. 37, n. 1, pp. 1-23.

Frank, S. L. (1928). The Problem of Reality. The Monist, vol. 38, n. 3, pp. 321-349.

Frank, S. L. (1946). God with Us: Three Meditations. Trans. N. Duddington, London: Jonathan Cape.

Frank, S. L. (1972). Ontologicheskoe dokazatel'stvo bytiya Boga. Po tu storonu pravogo i levogo. Paris: YMCA Press, pp. 107-151.

Frank, S. L. (1983). The Unknowable. An Ontological Introduction to the Philosophy of Religion. Trans. B. Jakim. Athens, OH: Ohio University Press.

Frank, S. L. (1992). The Essence and Leading Themes of Russian Philosophy. Soviet Studies in Philosophy, vol. 30, n. 2, pp. 28-47.

Frank, S. L. (1993). Man's Soul: An Introductory Essay in Philosophical Psychology. Trans. B. Jakim. Athens: Ohio University Press.

Frank, S. L. (2016). Iz zapisnoy knizhki 1944 goda. In G. Alyaev (ed.), Istoriya filosofï u vitchiznyaniy dukhovniy kul'turi. Poltava: ASMI, pp. 517-520.

Frank, S. L. (2017a). Dokazatel'stvo bytiya Boga. Filosofskiy zhurnal, vol. 10, n. 1, pp. 89-94.

Frank, S. L. (2017b). Ontologicheskoe dokazatel'stvo bytiya Boga. Filosofskiy zhurnal, vol. 10, n. 1, pp. 95-98.

Frank, S. L. (c. 1936). Vypiski iz raznykh knig. In Bakhmeteff Archive of Russian and East European History and Culture, Rare Book \& Manuscript Library. S. L. Frank Papers. Box 17.

Kant, I. (1996). Critique of Pure Reason. Trans. W. S. Pluhar, Indianapolis: Hackett Publishing Company.

Kotsyuba, V. I. (2001). K voprosu ob ontologicheskom dokazatel'stve (S. L. Frank-I. Kant). In N. $\mathrm{N}$. Trubnikova, et al. (eds.), Znanie $i$ traditsiia $v$ istorii mirovoi filosofii. Moscow: Rosspen, pp. 397-412.

Koyré, A. (1923). L’idée de Dieu dans la philosophie de St. Anselme. Paris: E. Leroux.

Lossky, N. (1951). History of Russian Philosophy. New York: International Universities Press.

Natorp, P. (1912). Kant und die Marburger Schule. Kant-Studien, vol. 17, pp. 193-221.

Nicholas of Cusa. (1996). Compendium. In Nicholas of Cusa on Wisdom and Knowledge. Trans. J. Hopkins. Minneapolis: The Arthur J. Banning Press, pp. 1385-1419.

Plotinus (1956). The Enneads. Trans. S. MacKenna, revised by B. S. Page. London: Faber and Faber.

Rojek, P. (2019). God and Cogito: Semen Frank on the Ontological Argument. Studies in East European Thought, vol. 71, n. 2, pp. 119-140.

Solovyov, V. (1995). Lectures on Divine Humanity. Trans. B. Jakim. Hudson, NY: Lindisfarne Press.

Swoboda, P. J. (1995). Windelband's Influence on S. L. Frank. Studies in East European Thought, vol. 47, n. 3/4, pp. 259-290.

Szatkowski, M. (ed.) (2012). Ontological Proofs Today. Frankfurt: Ontos Verlag. 
Publisher's Note Springer Nature remains neutral with regard to jurisdictional claims in published maps and institutional affiliations. 